\title{
THE INFLUENCE OF COOPERATIVE INTEGRATED READING AND COMPOSITION (CIRC) MODEL ON ELEMENTARY STUDENTS' LITERACY
}

\author{
Tatat Hartati ${ }^{1}$, Anggi Citra Apriliana ${ }^{2}$
}

${ }^{1,2}$ Primary Education, Universitas Pendidikan Indonesia, Bandung, Indonesia

${ }^{1}$ tatat@upi.edu, ${ }^{2}$ anggi.citra.apriliana@upi.edu

\author{
PENGARUH MODEL COOPERATIVE INTEGRATED READING AND \\ COMPOSITION (CIRC) TERHADAP LITERASI SISWA SEKOLAH DASAR
}

\section{ARTICLE} HISTORY

Submitted:

04 November 2020

04 November 2020

Accepted:

02 Januari 2021

$02^{\text {nd }}$ January 2021

Published:

16 Februari 2021

$16^{\text {st }}$ february 2021

\begin{abstract}
Abstract: The purpose of this study was to describe comprehensively the effect of Cooperative Integrated Reading and Composition (CIRC) model on the literacy abilities of elementary school students. The results of this study were expected to provide information about innovative models to be implemented in order to improve the literacy skills of elementary school students. This study utilized pre-experimental research method referring to research conducted on one experimental group whose sample was not randomly selected and there was no control group. This method was used to determine the effect of CIRC model on students' literacy skills after being given a treatment. The design in this study was one group pretest-posttest design. There was a significant effect of using Cooperative Integrated Reading and Composition (CIRC) model on the literacy abilities of fourth grade elementary school students. The average of overall pretest scores was 65.3. Then, it was obtained that the average posttest scores after the treatment was 86.1. Thus, there was a significant effect of CIRC model on the literacy abilities of elementary school students. as a result, the CIRC learning model could be implemented as an alternatives to increase the literacy skills in elementary school students.
\end{abstract}

Keywords: Learning model, CIRC, Literacy

Abstrak: Tujuan penelitian ini adalah untuk memperoleh gambaran secara komprehensif mengenai pengaruh model pembelajaran Cooperative Integrated Reading and Composition (CIRC) terhadap literasi siswa sekolah dasar. Hasil penelitian ini diharapkan dapat memberikan informasi mengenai model inovatif yang dapat digunakan untuk meningkatkan kemampuan literasi siswa sekolah dasar. Penelitian ini menggunakan metode penelitian preexsperimental yaitu penelitian yang dilakukan kepada satu kelompok eksperimen yang sampelnya tidak dipilih secara random dan tidak ada kelompok kontrol. Model ini digunakan untuk mengetahui pengaruh model CIRC terhadap kemampuan literasi siswa setelah diberikan perlakuan (treatment). Desain penelitian yang digunakan yaitu One group Pretest-posttest design. Hasil penelitian ini menyatakan bahwa terdapat pengaruh yang signifikan terhadap kemampuan literasi siswa sekolah dasar kelas IV melalui model Cooperative Integrated Reading and Composition (CIRC). Nilai rata-rata pretest siswa secara keseluruhan yaitu 65.3. Setelah diberikan perlakuan, diketahui nilai rata-rata posttest pada literasi siswa kelas IV secara keseluruhan yaitu 86.1. Model CIRC sangat tepat untuk meningkatkan keterampilan peserta didik dalam menyelesaikan soal cerita serta dapat memotivasi siswa karena pelaksanaan model ini dilakukan secara berkelompok sehingga peserta didik yang lemah dapat terbantu dalam menyelesaikan masalahnya. Model pembelajaran CIRC merupakan model pembelajaran kooperatif terpadu dalam pembelajaran membaca dan menulis untuk kelas tinggi sekolah dasar sehingga model pembelajaran CIRC dapat dijadikan sebagai salah satu pilihan alternatif dalam upaya peningkatan literasi pada siswa sekolah dasar.

Kata Kunci: Model Pembelajaran, CIRC, Literasi

CITATION

Hartati, T., \& Apriliana, A. C. (2021). The Influence of Cooperative Integrated Reading and Composition (CIRC) Model on Elementary Students' Literacy. Primary: Jurnal Pendidikan Guru Sekolah Dasar, 10 (1), 31 - 42 DOI: http://dx.doi.org/10.33578/jpfkip.v10i1.8091. 


\section{PENDAHULUAN}

Literasi diyakini oleh masyarakat maju sebagai kebutuhan yang sangat penting bagi setiap manusia sebagai warga masyarakat dunia yang bergerak sangat cepat. Sebagian besar masyarakat menganggap literasi sebagai hak asasi warga negara yang wajib difasilitasi oleh setiap negara. Oleh karena itu, banyak negara khususnya yang sedang membangun atau berkembang menjadikan literasi sebagai agenda utama pembangunan yang banyak menelan biaya. Hal ini karena kesadaran pemerintah bahwa literasi dapat memberi peluang terhadap pembangunan ekonomi dan sosial menuju kesejahteraan hidup, baik individu maupun masyarakat (Hartati, 2010). Sementara fakta-fakta menunjukkan peringkat literasi terbaru Indonesia berada pada posisi kedua dari bawah dari 61 negara yang diteliti. Indonesia hanya lebih baik dari Bostwana negara di kawasan Afrika Selatan (Agoestiowati, 2017). Fakta di atas berdasarkan studi deskriptif yang menguji sejumlah aspek, antara lain: perpustakaan, surat kabar, input sistem pendidikan, dan ketersediaan komputer.

Rendahnya kemampuan literasi Indonesia dapat dilihat dalam kajian PISA, PIRLS, TIMSS, EGRA USAID 2015, rendahnya IPM, belum meratanya GLS \& GLN, krisis karakter, kebangkrutan dan degradasi moral (Baswedan: 2014). Hal ini ditegaskan pula oleh Laporan Hasil Tes INAP (Indonesia National Assessment Program, 2016) kemampuan literasi membaca 38.88 dari 95 soal yang diujikan. Matematika hanya dapat menjawab 11 soal dari 85 soal yang diujikan.Untuk mata pelajaran IPA hanya 14 soal yang dapat dijawab benar dari 40 butir soal pilihan ganda dan uraian. Untuk kemampuan membaca INAP menyimpulkan antara lain: siswa tidak terbiasa menjawab pertanyaan yang menuntut penafsiran tingkat tinggi dan istilah khusus (non common sense), teks yang menuntut kemampuan berimaginasi, penjelasan, dan pendapat.

$$
\text { Pengertian literasi secara }
$$

tradisional dimaknai sebagai kemampuan menggunakan bahasa untuk membaca, menulis, mendengar dan bertutur. Dalam konteks masa kini, literasi merujuk kemampuan membaca dan menulis pada tahap yang memadai untuk berkomunikasi dalam suatu masyarakat yang literat. Lingkungan kelas yang literat adalah lingkungan kelas yang kaya dengan media kebahasaan dan cetakan (USAID Prioritas, 2014). Dari kelas yang literat akan menjadikan lingkungan sekolah yang literat. Dari sekolah literat diharapkan akan tumbuh komunitas sekolah yang literat yang pada akhirnya akan menjadikan bangsa Indonesia yang literat dan berdampak pada kemajuan dan peradaban bangsa.

Menurut UNESCO (Hartati, 2016) literasi adalah kemampuan mengenal, memahami, meramal, mencipta, berkomunikasi, menghitung, dan menggunakan bahan cetak dan penulisan dengan berbagai konteks. Literasi melibatkan satu kontinum pembelajaran yang memungkinkan seorang individu mencapai tujuannya, membangun pengetahuannya dan potensinya serta turut serta dalam pembinaan masyarakat. Literasi bukanlah sekadar keterampilan membaca dan menulis secara mekanis. Literasi meliputi tanggapan, pemahaman, dan kegiatan kehidupan sehari-hari yang tersusun dan diaplikasikan melalui 
kegiatan pembelajaran yang berkelanjutan. Literasi lebih dari sekedar membaca dan menulis, namun mencakup keterampilan berpikir menggunakan sumber-sumber pengetahuan dalam bentuk cetak, visual, akudio, dan digital (Teguh, 2017). Kemampuan ini melibatkan kegiatan mengumpulkan pengetahuan yang mengarahkan seseorang untuk memahami dan menggunakan bahasa yang tepat sesuai dengan situasi sosial. Dengan demikian, dalam konteks sekarang, literasi memiliki makna yang luas. Krisch dan Jungelbut (Hartati, 2016) mendefinisikan literasi kontemporer sebagai kemampuan seseorang dalam menggunakan informasi tertulis atau cetak untuk mengembangkan pengetahuan sehingga mendatangkan manfaat bagi masyarakat.

Dalam dua dekade terakhir, penelitian tentang literasi banyak diminati karena diketahui $43 \%$ penduduk dunia tergolong manusia yang memiliki kemampuan literasi rendah dan mereka terdiri atas golongan ekonomi lemah (miskin). Sebagian dari mereka (17\%), mereka bergantung pada bantuan makanan dari pemerintah, sementara yang lainnya (70\%) tidak memiliki pekerjaan tetap (pekerjaan sambilan). Kemampuan literasi yang rendah senantiasa dikaitkan dengan pendapatan, pekerjaan serta pendidikan yang rendah dan kemiskinan yang turuntemurun (Hartati, 2011).

$$
\text { Hasil penelitian tentang }
$$

kemampuan literasi pelajar Indonesia pernah dipublikasikan oleh Programme for International Student Assessment, Pusat Penilaian Pendidikan, 2003) yang menyimpulkan rendahnya kemampuan literasi pelajar Indonesia yang berumur 15 tahun. Menurut Yusuf (Toharudin, et.al., 2011) tentang laporan PISA tahun 2003, prestasi literasi pelajar Indonesia menduduki peringkat ke-38 dari 41 negara yang dijadikan sampel penelitian. Hasil penelitian ini menunjukkan bahwa kemampuan baca-tulis pelajar Indonesia jauh tertinggal jika dibandingkan dengan negara lain, misalnya, dengan negara tetangga Thailand yang menduduki peringkat ke-32. Prestasi literasi pelajar Indonesia hampir sama dengan prestasi pelajar Macedonia dan sedikit di atas prestasi pelajar Peru dan Albania. Kualitas pendidikan Indonesia yang rendah itu ditunjukkan pula dalam kategory The Primary Years Program yang menyatakan bahwa dari 146.052 SD di Indonesia hanya delapan sekolah saja yang mendapat pengakuan dunia, demikian pula peringkat SMP hanya delapan sekolah yang masuk kategori The Middle Years Program dari 20918 SMP. Untuk peringkat SMA hanya tujuh sekolah yang mendapat pengakuan dunia dari 8036 SMA (Balitbangdikbud, 2003). Rendahnya angka literasi dalam hal ini membaca, menulis dan berhitung (Calistung) menunjukkan bahwa pendidikan umum di Indonesia masih bergerak pada level paling mendasar.

Berdasarkan permasalahan di atas, melatarbelakangi peneliti untuk melakukan penelitian mengenai kemampuan literasi siswa sekolah dasar. Salah satu model pembelajaran untuk mengembangkan literasi siswa sekolah dasar yaitu dengan mengimplementasikan model pembelajaran Cooperative Integrated Reading and Composition (CIRC). Model pembelajaran CIRC merupakan model pembelajaran kooperatif yang dalam praktiknya memadukan keterampilan membaca dan menulis secara terintegrasi. Terdapat penelitian terdahulu yang telah menerapkan model CIRC diantaranya 
Sulistiantini, et.al (2014) dengan judul penelitian Pengaruh CIRC terhadap Keterampilan Membaca Pemahaman Siswa Kelas V Gugus XI Kec. Buleleng, Yudasmini, et.al (2015) dengan judul penelitian Pengaruh Model Pembelajaran CIRC (Cooperative Integrated Reading and Composition) terhadap Minat Baca dan Kemampuan Memahami Bacaan pada Siswa Kelas VI Di Sekolah Dasar Gugus Buruan. Delviani, et.al (2016) dengan judul penelitian Penerapan Model Kooperatif Tipe CIRC (Cooperative Integrated Reading and Composition) Berbantuan Media Puzzle Kalimat untuk Meningkatkan Kemampuan Membaca Anak dalam Menentukan Pikiran Pokok. Penelitian-penelitian tersebut lebih menekankan penerapan model pembelajaran CIRC pada keterampilan membaca pemahaman dan minat baca siswa sekolah dasar tetapi kurang menekankan pada aspek menulis.

Berdasarkan penelitian-penelitian terdahulu tersebut, melatarbelakangi peneliti untuk melaksanakan penelitian menggunakan model pembelajaran Cooperative Integrated Reading and Composition (CIRC) terhadap literasi siswa sekolah dasar baik pada aspek membaca maupun aspek menulis. Adapun tujuan penelitian ini adalah untuk memperoleh gambaran secara komprehensif mengenai pengaruh model pembelajaran Cooperative Integrated Reading and Composition (CIRC) terhadap literasi siswa sekolah dasar. Hasil penelitian ini diharapkan dapat memberikan informasi mengenai model inovatif yang dapat digunakan untuk meningkatkan literasi siswa sekolah dasar.

\section{KAJIAN TEORI}

Literasi adalah kemampuan bahasa seseorang (menyimak, berbicara, membaca, dan menulis) untuk berkomunikasi dengan cara yang berbeda sesuai dengan tujuannya. Sulzvy (Hartati, 2016) mengartikan literasi secara sempit yaitu literasi sebagai kemampuan membaca dan menulis. Ia juga mencangkup bagaimana seseorang berkomunikasi dalam masyarakat. Literasi juga bermakna praktik dan hubungan yang terkait dengan pengetahuan, bahasa, dan budaya.Hal senada Education Development Center (Mayuni, 2017) secara umum menjelaskan, literasi merupakan kemampuan individu untuk menggunakan segenap potensi dan kecakapan yang dimiliki dalam hidupnya.

Berdasarkan jenisnya, terdapat 6 jenis literasi yang dikembangkan Kemendikbud, secara jelas terlihat pada gambar. 1 


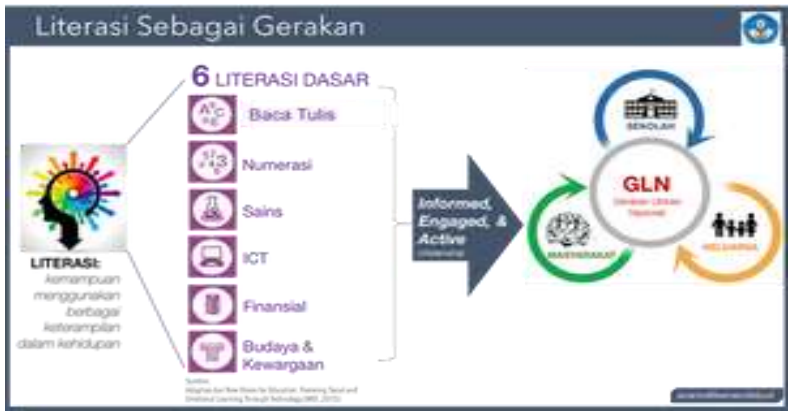

Gambar 1. Jenis Literasi Dasar

(Sumber: Mayuni, 2017)

Secara rinci keenam literasi dasar di atas dapat dijelaskan sebagai berikut.

1.Literasi Baca Tulis

Literasi baca tulis adalah melek pengetahuan dan kemampuan membaca, menulis, mencari, menelusuri, mengolah, dan memahami informasi untuk menganalisis, menanggapi, dan menggunakan bahasa dan sastra secara cendekia.

\section{Literasi Numerasi}

Literasi Numerasi adalah kemampuan menggunakan berbagai macam angka dan simbol-simbol yang terkait dengan matematika dasar untuk memecahkan masalah praktis dalam berbagai macam konteks kehidupan sehari-hari. Literasi numerasi juga berkaitan dengan kemampuan menganalisis informasi dan mampu mengolahnya ke dalam berbagai macam bentuk presentasi numerasi (grafik, tabel, bagan, dan sebagainya)

3. Literasi Sains

Literasi Sains adalah kemampuan untuk menggunakan pengetahuan sains, mengidentifikasi pertanyaan, menarik kesimpulan dalam rangka memahami serta membuat keputusan yang berkenaan dengan alam.

\section{Literasi digital}

Literasi digital adalah kecakapan (life skill) yang tidak hanya melibatkan kemampuan penggunaan perangkat teknologi, informasi, dan komunikasi semata, tetapi juga kemampuan bersosialisasi, kemampuan dalam pembelajaran, maupun sikap, berpikir kritis, kreatif, serta inspiratif sebagai kompetensi digital.

5.Literasi Finansial

Literasi Finansial adalah kemampuan untuk memahami bagaimana uang berpengaruh di dunia (bagaimaa seseorang mengatur untuk menghasilkan uang, mengelola uang, menginvestasikan uang dan menyumbangkan uang untuk mendorong sesama).

6. Literasi budaya dan kewarganegaraan

Literasi budaya dan kewarganegaraan adalah kemampuan untuk memahami, menghargai, dan berpartisipasi secara mahir dalam budaya.

Salah satu di antara enam literasi dasar yang diteliti dalam penelitian ini adalah literasi baca tulis. Membaca dan menulis merupakan literasi yang dikenal paling awal dalam sejarah peradaban manusia. Kemampuan membaca dan menulis harus dipupuk sejak dini. Tanpa memiliki kemampuan membaca dan menulis yang memadai sejak dini, anak akan mengalami kesulitan belajar pada masa selanjutnya (Apriliana, 2016). Keduanya tergolong literasi fungsional dan berguna besar dalam kehidupan sehari-hari. Dengan memiliki kemampuan baca-tulis, seseorang dapat menjalani hidupnya dengan kualitas yang lebih baik. Terlebih lagi di era yang semakin modern yang ditandai dengan persaingan yang ketat dan pergerakan yang cepat. Kompetensi individu sangat diperlukan agar dapat bertahan hidup dengan baik. 
Tujuan literasi secara umum adalah untuk membekali individu dengan kecakapan hidup (Mayuni, 2017). Literasi sangat penting bagi seseorang, hal ini dikarenakan keterampilan dalam literasi akan berpengaruh terhadap keberhasilan belajar mereka dan kehidupannya. Keterampilan literasi yang baik akan membantu seseorang dalam memahami teks, lisan, tulisan maupun gambar (Usaid Prioritas, 2014).

Secara rinci Kemendikbud (Mayuni, 2017) menjelaskan pentingnya Gerakan Literasi Nasional (GLN) sebagai berikut: a) membangun budaya literasi; b) menyiapkan Generasi Emas Indonesia 2045; c) menguatkan pendidikan karakter sebagai ruh dan fondasi pendidikan melalui harmonisasi olah hati (etik), olah rasa (estetik), olah pikir (literasi), dan olah raga (kinestetik); d) merevitalisasi dan memperkuat kapasitas ekosistem pendidikan; e) melestarikan kebudayaan dan jati diri bangsa Indonesia dalam mendukung Gerakan Nasional Revolusi Mental (GNRM).

Salah satu cara untuk mengembangkan literasi siswa sekolah dasar yaitu dengan mengimplementasikan model pembelajaran Cooperative Integrated Reading and Composition (CIRC). Slavin (Rianti, 2017) bahwa Cooperative Integrated Reading and Composition dikembangkan oleh Stevans dan Kolega pada akhir tahun 1980, menjadi teknik pembelajaran kooperatif yang digunakan dalam pembelajaran membaca, menulis, dan seni bahasa. Pembelajaran CIRC (Cooperative Integrated Reading and Composition) merupakan pembelajaran yang muncul dari konsep bahwa siswa akan lebih mudah menemukan dan memahami konsep jika mereka saling berdiskusi (Yudasmini,dkk., 2015). Sedangkan Abidin (2016) mengemukakan bahwa CIRC terdiri atas tiga unsur penting yakni kegiatan-kegiatan dasar terkait, pengajaran langsung, pelajaran memahami bacaan, dan seni bahasa menulis terpadu. Dalam CIRC, siswa ditempatkan dalam kelompok-kelompok kecil baik homogen maupun heterogen. Setiap kelompok tidak bisa mengikuti kuis hingga anggotaanggota di dalamnya menyatakan bahwa mereka benar-benar siap. Penghargaan (reward) diberikan kepada kelompok yang anggota-anggotanya mampu menunjukkan performa yang meningkat dalam aktivitas membaca dan menulis. Karena setiap anggota (Siswa) bekerja berdasarkan materi yang sesuai dengan level kemampuan membaca mereka, maka mereka memiliki kesempatan yang sama untuk bisa sukses dalam kelompoknya masing-masing. Konstribusi anggota pada masing-masing kelompoknya, didasarkan pada skor kuis yang mereka peroleh dan kompisisi (karangan) yang mereka tulis secara mandiri (Huda, 2011).

Berdasarkan pemaparan di atas tampak bahwa proses diskusi yang dilakukan oleh siswa dalam pembelajaran akan memudahkan siswa untuk menemukan dan memahami suatu konsep. Hal ini tentunya akan berpengaruh pada keinginan dan motivasi siswa dalam membaca dan menulis sehingga dapat mengembangkan literasi siswa sekolah dasar. Model pembelajaran CIRC merupakan model pembelajaran berkelompok untuk saling bekerja sama dan menemukan ide/pengetahuan baru terutama dalam bidang membaca dan menulis terpadu. Selain untuk meningkatkan kemampuan kerja sama antar siswa dan melatih rasa tanggungjawab pada siswa, model pembelajaran CIRC juga memiliki tujuan untuk meningkatkan kemampuan siswa dalam memahami isi bacaan sekaligus membina kemampuan menulis reproduksi atas bahan bacaan yang dibacanya (Abidin, 2015). Hal tersebut selaras dengan pendapat Halimah (2014) bahwa CIRC dalam prosesnya menggunakan kelompok-kelompok kooperatif untuk membantu para siswa mempelajari kemampuan memahami bacaan yang dapat diaplikasikan secara lugas. Dengan demikian. CIRC dapat membantu siswa meningkatkan kemampuan memahami isi bacaan dan melatih kemampuan menulis kembali isi bacaan dengan menggunakan bahasa sendiri. 


\section{METODE PENELITIAN}

Penelitian ini menggunakan metode penelitian pre-exsperimental yaitu penelitian yang dilakukan kepada satu kelompok eksperimen yang sampelnya tidak dipilih secara random dan tidak ada kelompok kontrol. Model ini digunakan untuk mengetahui pengaruh model CIRC terhadap literasi siswa setelah diberikan perlakuan (treatment).

Desain penelitian yang digunakan yaitu One group Pretest-posttest design. Pada desain penelitian ini siswa diberi tes pada saat sebelum dan setelah perlakuan dengan menerapkan model CIRC. Menurut (Borg \& Gall, 2010), desain ini dapat digambarkan sebagai berikut.

$$
\mathrm{O}_{1} \times \mathrm{O}_{2}
$$

Penelitian ini dilakukan di sekolah dasar yang berada di Kota Bandung. Subjek penelitiannya adalah guru dan siswa kelas IV sekolah dasar. Sampel dalam penelitian ini sebanyak 30 siswa yang terdiri 18 siswa perempuan dan 12 siswa laki-laki. Sampel dalam penelitian ini dipilih tidak secara acak tetapi dipilih secara langsung dengan demikian prosedur penyampelan dilakukan melalui teknik purpossive sampling atau dapat dikatakan pengambilan sampel dengan convinience sampling. Artinya sampel tersebut ada pada tempat dan waktu yang tepat serta without randomization.

Literasi yang diteliti dalam penelitian ini adalah literasi baca tulis. Adapun instrumen yang digunakan untuk mengumpulkan data berupa tes kemampuan membaca dan menulis siswa. Jenis intrumen yang digunakan adalah tes baca tulis berbentuk uraian yang dibedakan menjadi dua jenis yakni tes merespon karya fiksi dan tes membuat inti sari bacaan nonfiksi. Instrumen penilaian kemampuan siswa merespons karya disusun dengan berdasar pada beberapa indikator yang meliputi kemampuan: (1) mendeskripsikan seluruh elemen cerita, (2) mengorganisasikan cerita secara runtut, (3) ketepatan bahasa dalam merespon cerita, (4) memberikan respons terhadap cerita sesuai dengan sudut pandang dan isi bacaan secara tertulis. Teknik analisis data yang digunakan dalam penelitian ini dengan t-test (uji t). Jika diperoleh harga $\mathrm{t}$ hitung $>\mathrm{t}$ tabel pada taraf signifikansi $5 \%$ dengan $\mathrm{df}=\mathrm{n}-2$ maka dapat disimpulkan bahwa penggunaan model pembelajaran CIRC berpengaruh tinggi terhadap kemampuan literasi siswa. Sebaliknya, jika harga sig t hitung $<\mathrm{t}$ tabel maka dapat disimpulkan bahwa penggunaan model pembelajaran CIRC tidak memiliki pengaruh tinggi terhadap kemampuan literasi siswa. Namun, sebelum dilakukan pengujian, terlebih dahulu dilakukan analisis uji prasyarat untuk mengetahui homogenitas varians.

Langkah-langkah (sintak) yang digunakan dalam penelitian ini sebagai berikut.

\section{Tahap Prabaca}

a. Guru memperkenalkan cerita kepada siswa.

b. Setelah cerita diperkenalkan, siswa diberikan paket cerita yang terdiri atas buku cerita dan serangkaian kegiatan yang harus mereka lakukan dalam kelompoknya.

\section{Tahap Membaca}

a. Membaca berpasangan. Pada tahap ini, siswa membaca cerita dalam hati dan kemudian secara bergantian membaca keras cerita tersebut bersama pasangannya. Ketika rekannya membaca, pendengar mengikuti dan membetulkan setiap kesalahan yang dibuat oleh setiap si pembaca. Guru memberikan penilaian atas kinerja siswa secara berkeliling dan mendengarkan mereka membaca.

b. Menuliskan struktur cerita. Pada tahap ini, siswa menerima pertanyaan dari guru seputar cerita tersebut, yaitu: karakter, alur, latar, konflik, dan pemecahan masalah yang terkandung dalam cerita. Setelah siswa membaca setengah dari cerita, siswa diperintahkan 
berhenti membaca dan diperintahkan untuk melakukan kerja analisis atas berbagai pertanyaan di atas. Selanjutnya, siswa diminta menentukan prediksi akhir cerita tentang bagaimana cerita itu akan berakhir atau bagaimana konflik cerita dapat diatasi/dipecahkan. Kegiatan lain yang dilakukan adalah dengan meminta siswa menuliskan akhir cerita berdasarkan prediksi mereka. Pada saat akhir cerita, siswa diminta merespons isi keseluruhan cerita dan menuliskan beberapa paragraf tentang topik yang berkaitan dengan isi cerita tersebut.

c. Membaca nyaring. Para siswa diminta untuk menemukan kata-kata sulit yang terdapat dalam cerita dan membacakannya secara nyaring tanpa canggung dan ragu-ragu. Para siswa berlatih mengucapkan kata-kata sulit tersebut bersama rekannya. Siswa yang telah dapat membaca kata tersebut dengan benar melatih rekannya dalam kelompok agar mampu pula membaca.

d. Makna kata. Berbagai kata sulit yang mereka temukan dalam cerita selanjutnya ditentukan maknanya. Daftar kata sulit dan maknanya diberikan guru secara langsung pada kelompok membaca. Kegiatan ini dapat dilakukan dengan cara meminta siswa membuka kamus, memarafrasakan katakata sulit tersebut, atau menggunakan kata-kata tersebut dalam kalimat.

\section{Tahap Pascabaca}

a. Menceritakan kembali cerita. Setelah seluruh cerita dibaca dan dibahas dalam kelompok, siswa diminta membuat sinopsis cerita.

b. Pemeriksaan oleh pasangan. Sinopsis yang dibuat siswa selanjutnya ditukarkan kepada temannya sehingga satu sama lain dapat mengecek ketepatan sinopsis yang dibuat rekannya. Jika para siswa telah menyelesaikan semua kegiatan ini, pasangan mereka memberikan formulir tugas siswa yang mengindikasikan bahwa mereka telah menyelesaikan tugas tersebut.

c. Supaya kegiaan lebih menarik, guru memberikan permainan yang diberi nama merajut cerita. Tahapan pada permainan ini yaitu, setiap siswa dari masing-masing kelompok secara bergiliran akan menceritakan kembali isi cerita yang teah dibaca perkalimat. Dimulai dari kelompok pertama dengan siswa pertama sebagai pembuka cerita, kemudian kelompok kedua dengan siswa pertama menyambung potongan kalimat cerita dari kelompok sebelumnya dan seterusnya sampai cerita selesai. Selanjutnya penulis meminta perwakilan kelompok untuk berlomba mengacungkan tangan yang terlebih dahulu mengacungkan tangan dan berani menceritakan isi cerita memiliki penilaian tersendiri.

c. Tes. Pada tahap ini siswa diberi tes tentang pemahamaman isi cerita, menuliskan kalimat dari daftar kosa kata sulit, dan membaca daftar tersebut secara nyaring di depan guru. Pada saat tes siswa tidak boleh saling membantu. Hasil tes merupakan unsur utama skor tim.

\section{HASIL DAN PEMBAHASAN}

Berdasarkan hasil analisis data pada uji normalitas menggunakan uji liliefors didapatkan hasil yang dijelaskan pada tabel 1 . 
Tabel 1. Hasil Uji Normalitas $(\alpha=5 \%)$ Data hasil uji lilliefors

\begin{tabular}{lllllll}
\hline Kelas & $\mathrm{N}$ & $\bar{X}$ & $\mathrm{~S}$ & $\mathrm{~L}_{\text {hitung }}$ & $\mathrm{L}_{\text {tabel }}$ & Keterangan \\
\hline Pretest & 30 & 65.3 & 18.28 & 0.1915 & 0.3190 & $\mathrm{H}_{0}$ diterima \\
\hline Posttest & 30 & 86.1 & 10.18 & 0.2154 & 0.3190 & $\mathrm{H}_{0}$ diterima \\
\hline
\end{tabular}

Dari tabel di atas dapat dilihat bahwa $L_{\text {hitung }}$ untuk tes awal adalah 0.1915 sedangkan $L_{\text {tabel }}=0.3190$. Ini berarti $L_{\text {hitung }}<L_{\text {tabel }}$, artinya $H_{0}$ diterima. Sedangkan pada tes akhir $L_{\text {hitung }}$ adalah 0.2154 dan $L_{\text {tabel }}$ adalah 0.3190 maka $L_{\text {hitung }}<L_{\text {tabe }}$ dengan demikian $\mathrm{H}_{0}$ diterima. Maka tes awal (pretest) dan tes akhir (posttest) berdistribusi normal. Kemudian dilanjutkan dengan uji $t$ untuk menguji hipotesis. Adapun hipotesis yang digunakan sebagai berikut.

$\mathrm{H}_{0}$ :Tidak terdapat pengaruh yang signifikan penerapan model Cooperative Integrated
Reading and Composition (CIRC) terhadap literasi siswa sekolah dasar.

$\mathrm{H}_{1}$ : Terdapat pengaruh yang signifikan penerapan model Cooperative Integrated Reading and Composition (CIRC) terhadap literasi siswa sekolah dasar.

Kriteria pengujian: Jika : $-\mathrm{t}_{\text {tabel }} \leq \mathrm{t}_{\text {hitung }} \leq \mathrm{t}$ tabel maka $\mathrm{H}_{0}$ diterima.

Jika : $-\mathrm{t}_{\text {tabel }} \geq \mathrm{t}_{\text {hitung }} \geq \mathrm{t}_{\text {tabel }}$ maka $\mathrm{H}_{1}$ ditolak. Dari hasil perhitungan $\mathrm{t}_{\text {hitung }}$ dan $\mathrm{t}_{\text {tabel }}$ dengan taraf signifikasi 5\% diperoleh hasil yang tertera pada tabel 2 .

Tabel 2. Hasil Uji t ( $\alpha=5 \%)$

\begin{tabular}{lllllll}
\hline Kelas & $\mathrm{N}$ & $\mathrm{d}$ & $\mathrm{Sd}$ & $\mathrm{t}$ count & $\mathrm{t}$ tabel & Keterangan \\
Pretest & 30 & 20.8 & 14.71 & 3.4 & 2.5706 & $\mathrm{H}_{0}$ ditolak \\
Posttest & 30 & & & & \\
\hline
\end{tabular}

Dari tabel di atas, diperoleh nilai $\mathrm{t}_{\text {hitung }}$ $=3.4$ berada di luar daerah penerimaan $\mathrm{H}_{0}$ maka $\mathrm{H}_{0}$ ditolak dan $\mathrm{H}_{1}$ diterima, sehingga kesimpulannya adalah terdapat pengaruh yang signifikan penggunaan model Cooperative Integrated Reading and Composition (CIRC) terhadap literasi siswa sekolah dasar.

Berdasarkan hasil penelitian diperoleh hasil analisis data dan pengujian hipotesis. Dari hasil pengolahan data diketahui nilai pretest siswa secara keseluruhan memperoleh nilai terendah 44, nilai tertinggi 87 dan nilai rata-rata $(\bar{X}) \quad$ 65.3. Setelah diberikan perlakuan, diketahui nilai hasil posttest pada literasi dengan menerapkan model CIRC secara keseluruhan diperoleh nilai terendah 75 , nilai tertinggi 97 , dan nilai rata-rata $\bar{X} 86.1$. Berdasarkan uji normalitas dengan perhitungan menggunakan uji Lilliefors tes awal (pretest) diperoleh $L_{\text {hitung }}=0.1915$ dan $L_{\text {tabel }}=0.3190$. Sedangkan tes akhir (posttest) diperoleh $L_{\text {hitung }}$ $=0.2154$ dan $L_{\text {tabel }}=0.3190$. Ini artinya
$L_{\text {hitung }}<L_{\text {tabel }}$ dengan demikian $\mathrm{H}_{0}$ diterima, maka data hasil pretest dan posttest berdistribusi normal. Dari hasil pengolahan data menggunakan uji $\mathrm{t}$ dapat dilihat bahwa nilai $\mathrm{t}_{\text {hitung }}=3.4$ dan $\mathrm{t}_{\text {tabel }}=2.5706$. Sehingga $\mathrm{H}_{0}$ ditolak, artinya terdapat pengaruh yang signifikan penerapan model CIRC terhadap literasi siswa sekolah dasar.

Dapat disimpulkan bahwa hipotesis diterima artinya terdapat pengaruh yang signifikan mengenai penerapan model CIRC terhadap kemampuan literasi siswa kelas IV sekolah dasar. Hal ini dibuktikan, dengan beberapa temuan sebagai berikut: 1) Siswa mampu membuat intisari bacaan yang sesuai dengan judul, sesuai bentuk dan isinya lengkap. 2) Siswa mampu menyusun intisari bacaan sesuai dengan urutan isi dan didukung oleh kohesi dan koherensi antar paragraf. 3) Siswa mampu menyusun intisari bacaan dengan kalimat, pilihan kata, ejaan, dan teknik penulisan yang tepat. 4) Siswa mampu menyusun intisari bacaan yang sesuai dengan 
sudut pandang dan sikap penulis. Siswa mampu mendeskripsikan seluruh elemen cerita yang meliputi alur, tokoh, latar,dan sudut pandang dengan tepat. 5) Siswa mampu bekerja sama dengan kelompok dalam memecahkan masalah yang ditemukan serta mampu mengemukakan pendapat mengenai cara pemecahan masalah tersebut. 6). Siswa memiliki minat dan motivasi yang tinggi untuk mengikuti pelajaran dengan baik.

Berdasarkan temuan selama pembelajaran berlangsung, dapat disimpulkan bahwa model pembelajaran CIRC sangat cocok diterapkan pada siswa sekolah dasar dalam mengembangkan kemampuan literasi karena dapat membantu siswa memadukan kegiatan membaca dan menulis sebagai kegiatan integratif dalam pelaksanaan membaca. Hal ini sesuai dengan pendapat Abidin (2015) bahwa model pembelajaran CIRC pada dasarnya bertujuan untuk meningkatkan kemampuan siswa dalam memahami isi bacaan sekaligus membina kemampuan menulis bahan bacaan yang dibacanya. Penggunaan model pembelajaran CIRC (Cooperative Integrated Reading and Composition), menjadikan siswa dapat bekerja dalam kelompok dan saling membantu dengan siswa yang lemah serta dominasi guru berkurang sehingga situasi pembelajaran lebih menyenangkan, yang berarti keterampilan membaca pemahaman siswa akan mudah tercapai secara optimal. Hal ini sejalan dengan Kurniasih (2015) bahwa dalam pembelajaran CIRC setiap siswa bertanggung jawab terhadap tugas kelompoknya. Setiap anggota kelompok saling mengeluarkan ide-ide untuk memahami suatu konsep dan menyelesaikan tugas (task), sehingga terbentuk pemahaman dan pengalaman belajar yang menyenangkan. Cooperative Integrated Reading and Composition) tidak berpusat pada guru melainkan pada siswa, sehingga siswa sendiri yang aktif untuk membangun pengetahuannya. Peran guru dalam pembelajaran hanya sebagai fasilitator dan moderator yang memberikan tanggung jawab kepada siswa untuk memperoleh sendiri pengetahuan yang diperlukan melalui interaksi dengan anggota kelompoknya. Hal ini sesuai dengan pendapat Slavin (Halimah, 2014) bahwa model pembelajaran CIRC sangat tepat untuk meningkatkan pemahaman siswa pada materi pembelajaran. Dominasi guru dalam pembelajaran berkurang. Siswa termotivasi pada hasil secara teliti karena bekerja dalam kelompok. Para siswa dapat memahami makna soal dan saling mengecek pekerjaan. Membantu siswa yang lemah dalam memahami tugas yang diberikan. Meningkatkan hasil belajar, khususnya dalam menyelesaikan soal yang diberikan guru. Siswa dapat memberikan tanggapannya secara bebas, dilatih untuk dapat bekerjasama serta menghargai pendapat oranglain.

\section{SIMPULAN DAN REKOMENDASI}

Terdapat pengaruh yang signifikan penggunaan model Cooperative Integrated Reading and Composition (CIRC) terhadap literasi siswa kelas IV sekolah dasar dengan nilai pretest siswa secara keseluruhan memperoleh nilai rata-rata $\bar{X}$ 65.3. Setelah diberikan perlakuan, diketahui nilai hasil posttest pada pad akemampuan literasi siswa kelas IV secara keseluruhan memperoleh nilai rata-rata $\bar{X}$ 86.1. Berdasarkan uji normalitas dengan perhitungan menggunakan uji Lilliefors tes awal (pretest) diperoleh $L_{\text {hitung }}=$ 0.1915 dan $L_{\text {tabel }}=0.3190$. Sedangkan tes akhir (posttest) diperoleh $L_{\text {hitung }}=0.2154$ dan $L_{\text {tabel }}=0.3190$. Ini artinya $L_{\text {hitung }}<L_{\text {tabel }}$ dengan demikian $\mathrm{H}_{0}$ diterima, maka data hasil pretest dan posttest berdistribusi normal. Dari hasil pengolahan data menggunakan uji t dapat dilihat bahwa nilai $\mathrm{t}_{\text {hitung }}=3.4$ dan $\mathrm{t}_{\text {tabel }}=$ 2.5706. Sehingga $\mathrm{H}_{0}$ ditolak, artinya terdapat pengaruh yang signifikan mengenai penerapan model CIRC terhadap literasi siswa sekolah dasar sehingga model pembelajaran CIRC dapat dijadikan sebagai salah satu pilihan alternatif dalam upaya peningkatan literasi pada siswa sekolah dasar. 
DAFTAR PUSTAKA

Abidin, Y. (2015). Pembelajaran Bahasa Berbasis Pendidikan Karakter. Bandung: Refika Aditama.

Agoestiowati, R. (2017). Branding Sosial KKPK: Tinjauan pada Minat Literasi Anak-anak Majalah Ilmiah Institut STIAMI.

Apriliana, A.C. (2016). Picture Word Inductive Model (PWIM) dalam Pembelajaran Membaca dan Menulis Permulaan Di Sekolah Dasar. Jurnal Pedagogik Vol. IV, No. 1

Balitbangbud. (2003). Literasi Anak Indonesia. Jakarta: Kemendikbud.

Baswedan, A. R. (2014). Gawat Darurat Pendidikan di Indonesia. Jakarta: Kemdikbud.

Borg \& Gall. (2010). Applying Educational Research. Boston: Pearson Education, Inc.

Delviani, D. (2016). Penerapan Model Kooperatif Tipe CIRC (Cooperative Integrated Reading and Composition) Berbantuan Media Puzzle Kalimat untuk Meningkatkan Kemampuan Membaca Anak dalam Menentukan Pikiran Pokok. Jurnal Pena Ilmiah. [Online], Vol. 1, No. 1, Tersedia: https://ejournal.upi.edu/index.php/pena ilmiah/article/view/2935

Halimah, A. (2014). Metode Cooperative Integrated Reading and Composition (CIRC) Dalam Pembelajaran Membaca dan Menulis di SD/MI. Jurnal Pendidikan Dasar. [Online], Vol. 1. No. 1, 27-35. Tersedia: http://journal. uinalauddin.ac.id/index.php/auladuna/arti cle/view/539

Hartati, T. (2010). Penulisan Kreatif di Sekolah Dasar. Penang: USM.

Hartati, T. (2011). Pengembangan Literasi di Daerah Pinggiran Jawa Barat: Pedagogik Praktis yang Berkualitas. Bandung: Rizki Press.
Hartati, T. (2016). Multimedia dalam Pengembangan Literasi di Sekolah Terpencil. Jurnal Sekolah Dasar. 25 (1), hlm. 47-54.

Hartati, T. (2018). Pedagogi Bahasa Berperspektif Multiliterasi di Sekolah Dasar. Makalah pada FGD Pengajuan Guru Besar, Fakultas Ilmu Pendidikan.

Huda, M. (2011). Cooperative Learning. Yogyakarta: Pustaka Pelajar.

INAP. (2016). Hasil Indonesian National Assessment Programme. Jakarta: Kementerian Pendidikan dan Kebudayaan.

Kurniasih, I dan Berlin, S. (2015). Ragam Pengembangan Model Pembelajaran untuk Peningkatan Profesionalisme Guru. Cetakan Ke1. Yogyakarta: Kata Pena.

Mayuni, I. (2017). Pengantar Diskusi Penyusunan Pedoman dan Materi Gerakan Literasi Nasional untuk Guru. Jakarta: Badan Pengembangan dan Pembinaan Bahasa Kementerian Pendidikan dan Kebudayaan Republik Indonesia.

Pusat Penilaian Pendidikan. (2003). PISA (Programme for International Student Assessment). Jakarta: Depdiknas.

Riadi, M. (2017). Model Pembelajaran CIRC (Cooperative Integrated Reading and Composition). [Online]. Tersedia: https://www.kajian pustaka.com/2017/10/modelpembelajaran-circ.html

Rianti, H. (2017). Pengaruh Model Pembelajaran CIRC (Cooperative Integrated and Composition) Berbantuan Metode Garis Pada Soal Matematika. [Online]. Tersedia: http://repository.radenintan.ac.id/id/epr int $/ 951$

Sulistiantini. (2014). Pengaruh CIRC terhadap Keterampilan Membaca Pemahaman Siswa Kelas V Gugus XI Kec. Buleleng Tahun 2013. Jurnal Mimbar PGSD Universitas Pendidikan 
Ganesha. 2(1), 1-10. Tersedia: https://ejournal.undiksha.ac.id/index.p hp/JJPGSD/article/view/

Teguh, M. (2017). Gerakan Literasi sekolah Dasar. Prosiding Seminar Nasional "Aktualisasi Kurikulum 2013 melalui Gerakan Literasi Sekolah untuk Menyiapkan Generasi Unggul dan Berbudi Pekerti".

Toharudin, et.al. (2011). Membangun Literasi Sains Peserta Didik. Bandung: Humaniora.

USAID Prioritas. (2014). Pembelajaran Literasi Kelas Awal di LPTK. Jakarta: USAID.

Yudasmini, M. (2015). Pengaruh Model Pembelajaran CIRC terhadap Minat Baca dan Kemampuan Memahami Bacaan pada Siswa Kelas VI di Sekolah Dasar Gugus Buruan. $e$ Journal Program Pascasarjana Universitas Pendidikan Ganesha. [Online], 5(1), 1-9. Tersedia: https://www.neliti.com/publications/20 7279/pengaruhmodelpembelajarancirc-terhadap-minat-baca-dankemampuan-memahami-baca. 